\title{
Molecular Identification of Listeria Species from Some Processed Meat Products Using Specific Iap Gene and 16S rRNA Gene
}

\author{
Mona M. Hassan, ${ }^{1}$ Samia A. AbdAl-Aziz ${ }^{1}{ }^{*}$, Asmaa M. Megahed ${ }^{1}$, Hagar A. Abdel Rassoul ${ }^{2}$, \\ Yasser M. Mabrouk ${ }^{2}$
}

\begin{abstract}
Three kinds of processed meat (Luncheon, Burger , Minced meat) were examined for the presence of Listeria species. Collected samples purchased from local supermarkets were from three different Egyptian companies. All the bacterial isolates were cultured on specific media after pre-enrichment and enrichment cultures. The colonial morphology depends strongly up on the media used and the incubation conditions provided. (Oxford Listeria Agar Base) was used as specific medium for Listeria. The bacterial distribution of Listeria was, $\mathbf{2 . 2 2 \%}$ in Beef burger, $\mathbf{1 3 . 6 \%}$. in luncheon and there was no bacterial growth in minced meat. In this study; gram staining., morphological characterization, molecular identification using 16S rDNA partial sequencing and specific gene Iap gene of Listeria were carried out.
\end{abstract}

Keywords: Listeria Species- specichic PCR.

\section{INTRODUCTION}

Listeria considers anaerobic, non-spore, psychrophilic gram positive bacteria. It has the ability for salt tolerant and pathogenic for humans and animals that causing clinical manifestations such as gastroenteritis, encephalitis, meningitis and abortion (Ruppitsch et al., 2015; Lakicevic et al., 2014). Moreover, listeria can produce a biofilm at low temperatures to facilate persistent dissemination of this pathogen during food production (Allerberger et al., 2015).

Listeria entrance through the intestines to the liver where it replicates considers the first step in its pathogenesis and the cell mediated immunity is specific to clear and attack listeria infection. One of the most common clinical diagnosis and effect of listeria is the diarrhea that occurred due to direct invasion of the intestinal mucosal epithelium by the organism (Schuppler and Loessner, 2010).

The main means of prevention is through the promotion of safe handling, cooking and consumption of food. This includes washing raw vegetables and cooking raw food thoroughly, as well as reheating leftover or ready-to-eat foods like hot dogs until steaming hot (CDC, 2011) preventing listeriosis as a food illness.

\section{MATERIALS AND METHODS}

\section{Bacterial isolation}

A total of (18) samples of three kinds of processed meat from three different Egyptian companies collected from local supermarkets at Alexandria Governorate. The samples included (6) luncheon (6) beef burger, and (6) minced meat. The date production of all samples in July 2016 (Table1).

Table 1. the percentage of bacteria in each sample

\begin{tabular}{ccc}
\hline $\begin{array}{l}\text { Name } \\
\text { company }\end{array}$ & $\begin{array}{c}\text { Kind of procced } \\
\text { meat }\end{array}$ & $\begin{array}{c}\text { Percentage of } \\
\text { Listeria }(\%)\end{array}$ \\
\hline $\mathbf{P}$ & Beef burger (P) & $2.22 \%$ \\
& Luncheon(P) & $13.6 \%$ \\
A & Minced meat(P) & ----- \\
& Beef burger(A) & $0.44 \%$ \\
& Luncheon(A) & $7.33 \%$ \\
F & Minced meat(A) & ----- \\
& Beef burger(F) & ---- \\
& Luncheon(F) & $3.78 \%$ \\
& Minced meat(F) & ---- \\
\hline
\end{tabular}

For isolation of Listeria from the chosen processed meat samples, $2 \mathrm{~g}$ from each sample were mixed with 20 $\mathrm{ml}$ of Pre-enrichment broth medium( $1.5 \mathrm{~g}$ of beef extract was added to $2.5 \mathrm{~g}$ of peptone then fill up to $500 \mathrm{ml}$ $\mathrm{ddH}_{2} \mathrm{O}$ at pH 6.8 (Banwart, 1989), and left over night at $37^{\circ} \mathrm{C}$ with shaking. $4 \mathrm{ml}$ pre-enrichment media were added to $20 \mathrm{ml}$ of enrichment broth media that prepared with $2.5 \mathrm{~g}$ of Protease peptone, $0.5 \mathrm{~g}$ of Difco bile salt, $5 \mathrm{~g}$ of calcium carbonate and $15 \mathrm{~g}$ of sodium thiosulfate

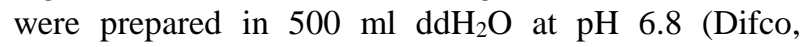
1984), and incubated with shaking over night at $37^{\circ} \mathrm{C}$. Each sample was diluted after growth into two concentration $10^{-5}$ and $10^{-10}$ and transferred to specific

DOI: $10.21608 / A S E J A I Q J S A E .2019 .36518$

${ }^{1}$ Nucleic acids research department, Genetic Engineering and

biotechnology Institute, City of Scientific research and

Technological Applications, new Borg El Arab, Alexandria, Egypt

${ }^{2}$ Department of Genetics, Faculty of Agriculture (El-Shatby),

Alexandria University, Alexandria, Egypt

*Correspondence: Samia AbdAllah AbdAl-Aziz; samiaabdelaziz1@yahoo.com

Received May 27, 2019, Accepted June 23, 2019 
media Oxford Listeria Agar Base (57.5 g of Oxford Listeria Agar Base powder was dissolved in $1000 \mathrm{ml}$ $\mathrm{ddH}_{2} \mathrm{O}$ ) (Vanderzant and Splittstoesser, 1992). Samples were incubated at $37^{\circ} \mathrm{C}$ overnight with agitation at 110 rpm. The bacterial morphology identification was carried out visually and by microscopic examination after Gram staining test.

\section{Morphological identification of Listeria species.}

Bacterial isolates were grown Oxford Listeria Agar Base according to (MacFaddin, 1985) and (Vanderzant and Splittstoesser, 1992). Morphological identification was assessed visually and microscopically. A clean, grease free slide was taken and the smear of suspension on the clean slide with a loop ful of sample was prepared then Air dried and heat fixed Crystal Violet was poured and kept for about 30 seconds to 1 minute and rinsed with water. The gram's iodine was flooded for 1 minute and washed with water. Then washed with 95\% alcohol or acetone for about 10-20 seconds and rinsed with water. Safranin was added and left for about 1 minute and washed with water then Air dried, Blot dry and Observed under Microscope (Jacquelyn and Black, 1993).

\section{Molecular analysis}

Iap gene-specific PCR amplification, 16S rDNA sequencing and phylogenetic analysis were used to more confirm the identification of the Listeria spp.

\section{Extraction of DNA}

DNA was extracted from Bacterial samples using modified method instruction reported by (John et al., 1990). The bacterial samples were renewed and cultured for 18 hours on nutrient broth and centrifuged at 1000 rpm for 15 minutes to get the pellet. $467 \mu 1 \mathrm{TE}$ buffer $(\mathrm{pH} 8),(30 \mu 110 \%$ SDS, $3 \mu$ Protienase $\mathrm{K}(20 \mathrm{mg} / \mathrm{ml})$ were added on pellet in 1.5 sterilized $1.5 \mathrm{ml}$ tube and incubated at $37^{\circ} \mathrm{C}$ for 1 hour. After incubation, 500 $\mu 1$ phenol chloroform isoamyl alcohol (24:25:1), $(\mathrm{pH} 8)$ was added and gently inverted for 5 minutes and centrifuged at $1000 \mathrm{rpm}$ for 10 minutes. The DNA was precipitated with $3 \mathrm{M}$ sodium acetate $(\mathrm{pH}$ 5.2) and 600 $\mu \mathrm{l}$ cold isopropanol and kept overnight at $-20^{\circ} \mathrm{C}$, then centrifuged at $12000 \mathrm{rpm}$ for 15 minutes at $4^{\circ} \mathrm{C}$. The pellet washed twice with $70 \%$ Ethanol and then centrifuged at $12000 \mathrm{rpm}$ for 5 minutes at $4^{\circ} \mathrm{C}$. The pellet was washed with $70 \%$ ethanol, dried and finally dissolved in Tris-EDTA (TE) buffer, $\mathrm{pH}$ 7.4. The concentrations and purities of DNA were determined by using nanodrop machine (A260 / A280) and kept at $20^{\circ} \mathrm{C}$ for furthers molecular examinations.

\section{Specific PCR for detection of Listeria spp}

The Iap gene was used as specific gene to identify the Listeria species as described by (Veriti ${ }^{\mathrm{TM}}$ thermal cycler USA). The primer Iap (one of a set of virulence genes specific for Listeria) $\mathrm{F}($ :CAAACTGCTAACACAGCTACT) and Iap R:(TTATACGCGACCGAAGCCAAC) were used for amplification of Iap gene from bacterial DNA.The PCR reaction was carried out in $25 \mu$ total volume containing (12.5 $\mu 1$ master mix (thermos), 10 p.mol each of forward and reverse primers, and $10 \mathrm{ng}$ of genomic DNA in (BioRad, USA ) thermo-cycler. PCR conditions were: $94^{\circ} \mathrm{C}$ for $3 \mathrm{~min}$ : 30 cycles of $95^{\circ} \mathrm{C}$ for $15 \mathrm{sec}$, Annealing: $58^{\circ} \mathrm{C}$ for 30 sec., extension: $72^{\circ} \mathrm{C}$ for 50 sec, and final extension: $72^{\circ} \mathrm{C}$ for $10 \mathrm{~min}$. Amplified products were fractionated by electrophoresis in $2 \%$ $(w / v)$ agarose/TBE gels, visualized, and documented usinga gel documentation and image analysis system (Alfa Imager M 1220, Documentation and Analysis System, Canada) as shown by (Bubert et al .,1999).

\section{Amplification of 16S rRNA gene and Sequencing}

16S rRNA gene was amplified for all the examined isolates using universal primer16SF:(AGAGTTTGATCCTGGCTCAG),and16S R:(GGTTACCTTGTTACGACTT (James et al., 2010).Amplification was done in $25 \mu \mathrm{l}$ reaction with $12.5 \mu$ master mix (thermos,), $10 \mathrm{ng}$ of genomic DNA and 10 p.mol each of forward and reverse primers. The PCR program was performed in thermo-cycler (BioRad, USA ) as follow: Initial denaturation at $95^{\circ} \mathrm{C}$ for 5 mins then followed by 34 cycles of $95^{\circ} \mathrm{C}$ for $1 \mathrm{~min}$, annealing at $55^{\circ} \mathrm{C}$ for $1 \mathrm{~min}$ and extension at $72^{\circ} \mathrm{C}$ for $1 \mathrm{~min}$. A final extension at $72^{\circ} \mathrm{C}$ for 10 mins. PCR products were separated on agarose gel electrophoresis using $2 \%$ agarose $(\mathrm{w} / \mathrm{v})$ in $0.5 \mathrm{X}$ TBE buffer that stained with $0.5 \mu \mathrm{g} / \mathrm{ml}$ ethidiumbromide. The gel was then photographed using gel documentation system. PCR products were purified by EZ-10 Spin Column DNA Gel Extraction Kit (Bio Basic, Canada), following the manufacturer's instruction. The DNA sequences for $16 \mathrm{~S}$ rDNA were determined by Macro gene Company (South Korea). The sequences were subjected to pairwise and multiple alignment using CLUSTAL W version 2 (http://www.ebi.ac.uk/Tools/msa/clustalw2, Thompson et al., 1997).

\section{RESULTS AND DISCUSSION}

Listeria $s p$ including $L$. monocytogenes have ubiquitous nature and psychotropic growth to be found in food samples. Due to raw food consumption or recontaminated heat processed food stuffs cause listeriosis that may be led to death in some sensitive groups. Many precautions should be considered to prevent listeriosis 
such as no consumption of raw and insufficiently cooked food of animal origin, storage conditions and cross contamination (Ray, 2004). In addition to, many advanced approaches such as understand the characteristic of listeria, environmental impact and influence of virulence factors to control and prevent listeriosis (Buchanan et al., 2017). In this study, three kinds of processed meat products (Luncheon, Burger, and Minced meat) were used and checked to examine the presence of listeria using morphological and molecular methods including specific medial culture, gram staining specific -specific PCR, 16S rRNA amplification and sequence confirmation.

\section{Morphological characterization of bacteria on specific medium and by Gram staining:}

The results of bacterial colonies were shown in Fig (1) in which the bacteria gave black colored or short rods colonies on specific medium (fig. 2) respectively, after gram staining.

The results indicated that Listeria can grow on a variety of processed meat products. The distribution of Listeria in beef burger was $2.22 \%$, and $0.44 \%$ for the company $\mathrm{P}$ and $\mathrm{A}$ respectively. While the highest percentage of Liseteria was $13.6 \%, 7.33 \%, 3.78 \%$ and found in Luncheon for the three companies. The minced meat samples were totally negative in all the three companies (table 1). These results were agreed with (Mohamed et al., 2016) who found that $L$. monocytogenes were confirmed distributed in beef burgers samples (4\%), minced meat (4\%) and Luncheon (4\%).

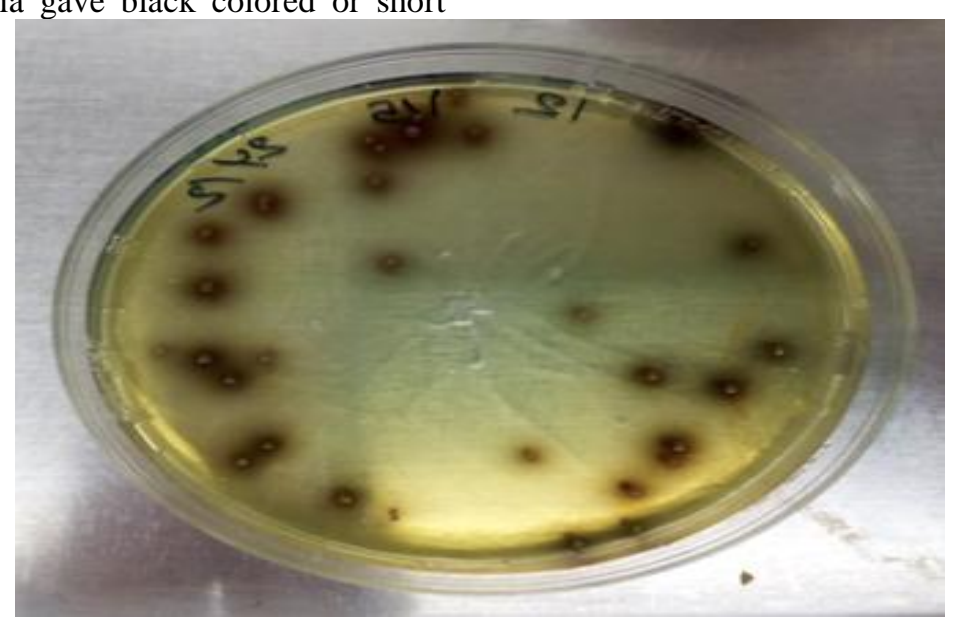

Fig. 1. Colony morphology of Listeria spp. after culture on Oxford Listeria Agar Base medium (appeared a black colonies)

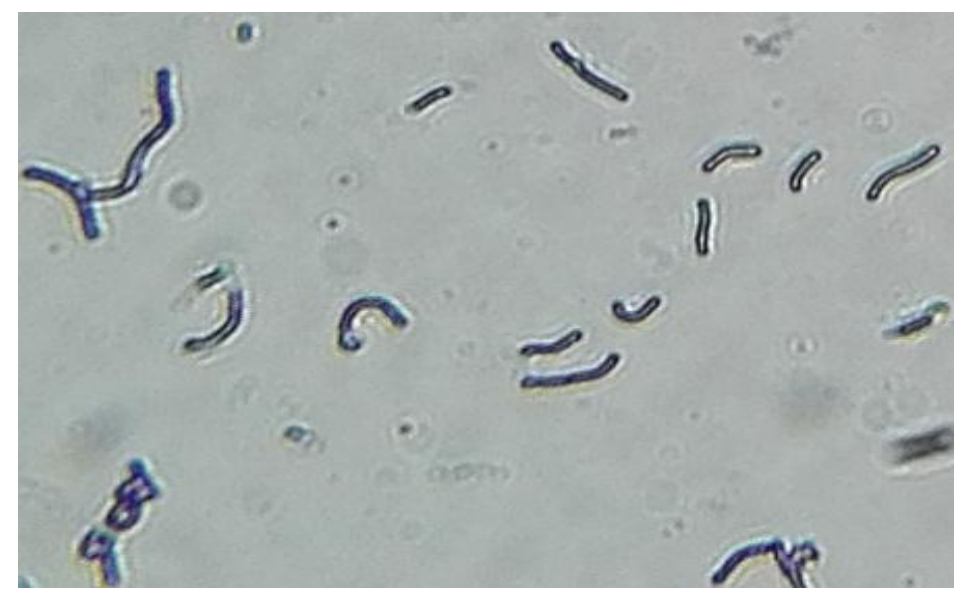

Fig. 2. Gram staining of Listeria spp 


\section{Molecular identification}

16S rRNA sequencing analysis:

16S rRNA gene PCR products were appeared as specific fragment (about $1500 \mathrm{bp}$ ) in all samples after specific amplification of 16S rRNA gene using universal primer as shown in fig (3). The obtained amplicons were later subjected to further analysis.
The purified $1500 \mathrm{bp}$ band of the16s rRNA gene from two isolates was subjected to sequencing using 3110 automated DNA sequencer model (SENSQUIST Lab cycler GmbH Germany) At the city of scientific researches and technological applications. The following partial sequence was obtained for samples.

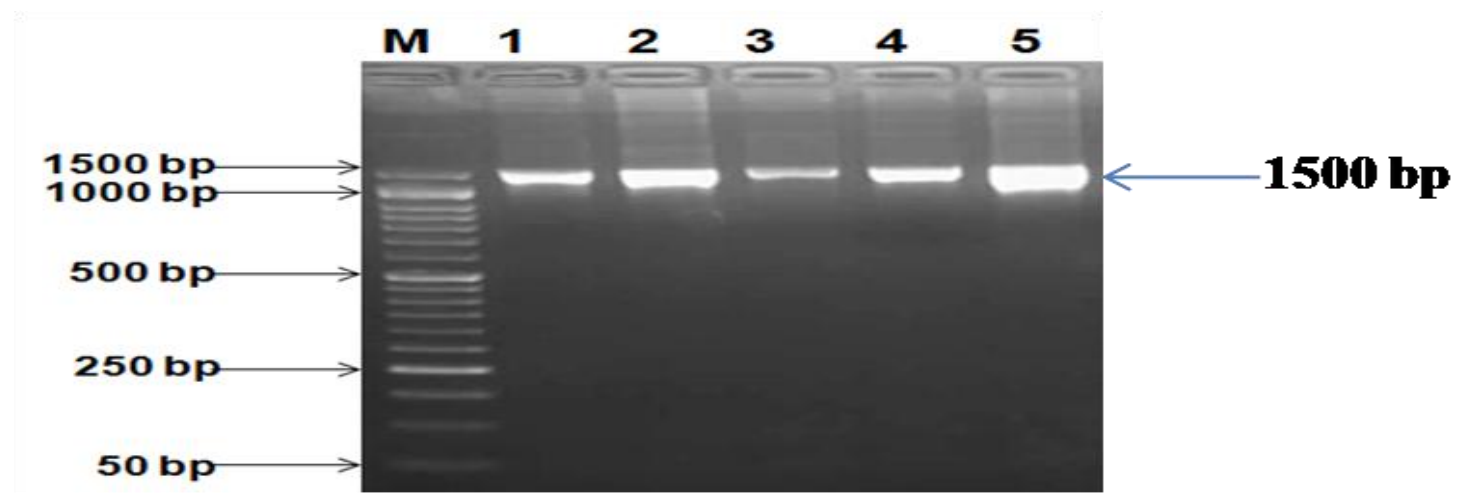

Fig.3. Agarose gel electrophoresis of 16s rRNA gene PCR products. Lane M: 1.5 Kb DNA ladder, lanes 1-5: 16s rRNA PCR products (1500 bp)

\begin{abstract}
>Listeria spp1
ACGTCTTTGTGTTCATGCAGTCGTGCGGAAGACGGAGCTTGCTCCCGGATGTTAGCGGCGGACGGGTG AGTAACACGTGGGTAACCAGCCTGTAAGACTGGGATAACTCCGGGAAACCGGAGCTAATACCGGATA GTTCCTTGAACCGCATGGTTCAAGGATGAAAGACGGTTTCGGCTGTCACTTACAGATGGACCCGCGGC GCATTAGCTAGTTGGTGAGGTAACGGCTCACCAAGGCGACGATGCGTAGCCGACCTGAGAGGGTGATC GGCCACACTGGGACTGAGACACGGCCCAGACTCCTACGGGAGGCAGCAGTAGGGAATCTTCCGCAAT GGACGAAAGTCTGACGGAGCAACGCCGCGTGAGTGATGAAGGTTTTCGGATCGTAAAGCTCTGTTGTT AGGGAAGAACAAGTGCAAGAGTAACTGCTTGCACCTTGACGGTACCTAACCAGAAAGCCTCGGCTAAC TACGTGCCAGCAGCCGCGGTAATACGTAGGTGGCAAGCGTTGTCCGGAATTATTGGGCGTAAAGGGCT CGCAGGCGGTTTCTTAAGTCTGATGTGAAAGCCCCCGGCTCAACCGGGGAGGGTCATAGGAAACTGGG AAACTTGAGTGCAGAAGAGGAGAGTGGAATCCCACGCGTTGCGGAGAAATGCGTAGAGATGTGGACT AACACGGGTGGTGATCGTGTCTGTTTCGTCTGTTACTGATGCTCAGGATCGAATGCGGGCGGGAGCGA ACACCATTAGATCCGGTGTTCCTCCACGTCTCTAACGATGTCTGCTCAGCGCGAGGGAGTTCCCTCTCC TTTGTTGGTGCTCATGACTTCATAAAGTACTCCGACCGGTCCAGTGCTGACACGAGGTGTGTTTTCATA TCAGGATTTAAACAAGCCCCCTGCAAGAGCCGTGGCAGCCCTGATGATTTATTGAGAAGCATCGCCAA ACATACCGTTATCACGCGCTGTGGACTCGCTCTGAAAACCCGTAGAGATATGGCTTTTACAGTCCCGGT ACAAGAGTGCACGGATGGTAGCATGGCCAGTCTGTCAGCTCGGTAACAGTGAGAATGTTTGGTAGCTC ACGCACCTACGTCCATCCTGGACGTTAGCTGCCGAGGAT

\section{$>$ Listeria spp2}

CCCCCTCTGTCATTTATGCAGTCGAGCGATGGATTAGAGCTTGCTCTTATGAAGTTAGCGGCGGACGG GTGAGTAACACGTGGGTAACCTGCCCATAAGACTGGGATAACTCCGGGAAACCGGGGCTAATACCGG ATAACATTTTGAACCGCATGGTTCGAAATTGAAAGGCGGCTTCGGCTGTCACTTATGGATGGACCCGC GTCGCATTAGCTAGTTGGTGAGGTAACGGCTCACCAAGGCAACGATGCGTAGCCGACCTGAGAGGGTG ATCGGCCACACTGGGACTGAGACACGGCCCAGACTCCTACGGGAGGCAGCAGTAGGGAATCTTCCGCA ATGGACGAAAGTCTGACGGAGCAACGCCGCGTGAGTGATGAAGGCTTTCGGGTCGTAAAACTCTGTTG TTAGGGAAGAACAAGTGCTAGTTGAATAAGCTGGCACCTTGACGGTACCTAACCAGAAAGCCACGGCT AACTACGTGCCAGCAGCCGCGGTAATACGTAGGTGGCAAGCGTTATCCGGAATTATTGGGCGTAAAGC GCGCGCAGGTGGTTTCTTAAGTCTGATGTGAAAGCCCACGGCTCAACCGTGGAGGGTCATTGGAAACT GGGAGACTTGAGTGCAGAAGAGGAAAGTGGAATTCCATGTGTAGCGGTGAAATGCGTAGAGATATGG
\end{abstract}


AGGAACACCAGTGGCGAAGGCGACTTTCTGGTCTGTAACTGACACTGAGGCGCGAAAGCGTGGGGGA GCAAACAGGATTAGATACCTGTGGTAGTCCACGCCGTAAACGATGAGTGCTAAGTGTTAGAGGGTTTT CCGCCCCTTTTAGTGCTGAAGGTTAACGCATTTAAGCCACTCCGCCCTGGGGGGAGTACGGCCCGCGA AGGTCTTGAAACTTCAAAAGGTAAATTAGAACGGGGCGGCCCCGGCACAAGTCTGGTGGCAGCATGAT GGGTTTAAATTACGAAAGTCAACGCCGCAAGAATCCTTTACCCAGGTCTTTGGACGATTCATTCTGAC ACCCGTAGAGATTAGGTGCCTTTCTCCTTCGGGAGGCAGAGCTGACCAGGATGCGTGCATGGCTTGTC GTCCAGCTTCGTGTCGTGAGAATGTTTTGCGATTCAGTAACTGCTATCGTAGACGCAAA

The increasing signal generation of $16 \mathrm{~S}$ rRNA analysis due to its a target for genes and species bacteria identification by detection the conserved and variable regions of the gene (Gopo et al., 1988; Maureau et al., 1989). Otherwise, 16S rRNA gene test has been dictated by multiple copies (104) of rRNA in microorganisms. On the other hand, 16S rRNA is the most famous gene used in phylogenetic studies of the genera of archaea and bacteria. Recently, universal primers have been used to amplify the conserved region of $16 \mathrm{~S}$ rRNA through the PCR technique (Leight et al., 2018).

Species-specific primers targeted against virulence genes of Listeria .

The virulence factor occurrence in $L$. monocytogenes which are encoded on a multigene family was effective in the pathogenesis. Some of these virulence genes like Iap gene were attractive molecular markers for detection of Listeria sp by development of PCR-based assays. Iap gene encodes the protein p60, which is common to all Listeria species (Bubert, et al.,1999). So, in this study, we used one set of primers based on Iap gene in its PCR assays. Molecular identification of Listeria through Iap specific gene (780 bp) was illustrated in Fig. (4).

Specific primers were designed as selective target of virulence genes in listeria monocytogenes such as Iap gene to delineate the different species of listeria spp as reported by Klein and Juneja (1997). Iap gene was detected in all Listeria strains (100\%) and these results were similar to those obtained by Gelbicova and
Karpiskova (2012) in the Czech Republic, Jamali et al., (2015) in Iran, Moreno et al. (2014) in Brazil, and Wang et al., (2015) in China. Moreover, (Bhunia, 2008; Furrer et al., 1991, and Swaminathan et al., 2007) have been reported that the presence of multiple virulence factors in L. monocytogenes strains such as Iap gene may be act as a potential cause of human listeriosis due to improved entry into cells, escape from the vacuole and intracellular spreading. For this purpose, Iap gene was selected in this study because it is a common virulence factor in all members of the genus Listeria and it has been been indicated that there were conserved regions at 50 and 30 ends, while the internal portions are highly specific (Bubert et al., 1992). In addition to, Iap gene of L. monocytogenes encodes the major extracellular protein (P60) (Kuhn and Goebel 1989), which has been shown as a bio-vital role and essential murein hydrolase required for adherence/invasion of the organism to the targeted eukaryotic cell. Recently, it has been shown that the corresponding Iap gene portion is also hypervariable in length in different isolates belonging to the same serotypes, thereby, can be used in identification of different strains of L. monocytogene. It can't be neglected that the differences among the results of various studies regarding the prevalence of Listeria spp. may be due to several factors such as different isolation methods, type of food samples, season, geographical location and the conditions of packaging, handling, and storage (Bhunia, 2008; Ray, 2004). 


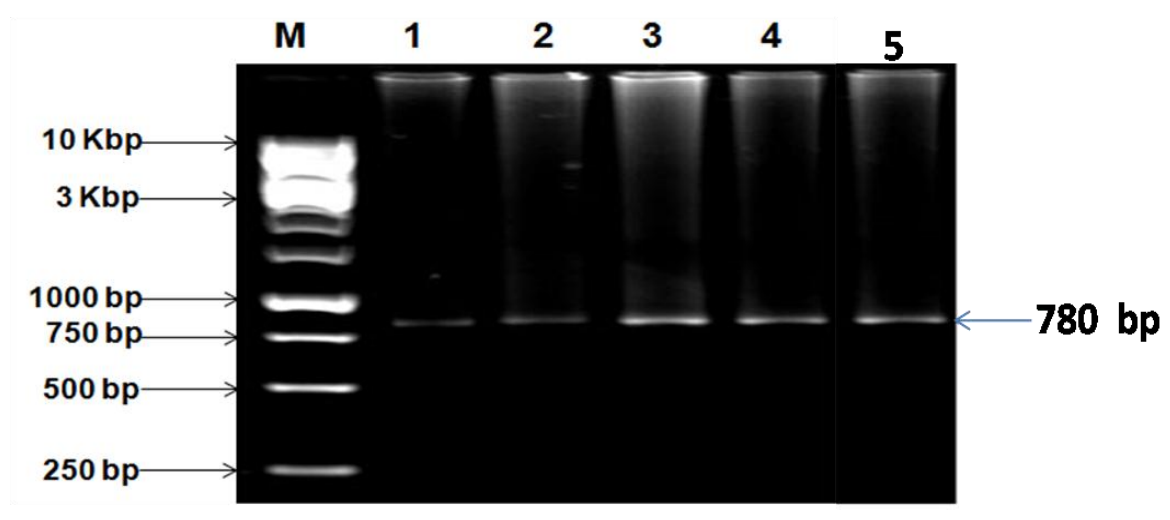

Fig. 4. Agarose gel electrophoresis of_Listeria Iap gene PCR products. Lane M: 10 Kbp DNA ladder, lanes 15: Listeria Iap gene PCR products (780 bp)

\section{REFERENCES}

Allerberger, F., Z. Bagó, S. Huhulescu and A.Pierzka. 2015. Listeriosis: the dark side of refrigeration and ensiling. In: SingA (Ed.), Zoonoses - Infections Affecting Humans and Animals Focus on Public Health Aspects. Springer Verlag, Heidelberg, Germany. pp:249-286.

Banwart, G.J. 1989. Basic food Microbiology (2 ${ }^{\text {nd }}$ ed.) AVI Book, Van Nostrand Reinhold, NewYork, pp:11-48.

Bhunia, A. K. 2008. Foodborne microbial pathogens. New York: Springer.pp:51-91.

Bubert, A., I. Hein, M. Rauch, A. Lehner, B. Yoon, W. Goebel and M. Wagner.1999. Detection and differentiation of Listeria spp. by a single reaction based on multiplex PCR. Appl Environ Microbiol 65:46884692

Bubert, A., H. Inge , R. Marcus , L. Angelika, S. Y. Byoung, G. Werner and W. Martin .1999.Detection and Differentiation of Listeria spp. by a Single Reaction Based on Multiplex PCR .Appl Environ Microbiol.; 65(10): 4688-4692.

Buchanan, R. L., G.M. G. Leon, M. H. Melinda, C. J. Timothy and C. W. Richard. 2017.A review of Listeria monocytogenes: An update on outbreaks, virulence, doseresponse, ecology, and risk assessments Food Control 75: 1-1

CDC. Center for Disease Control and Prevention . 2011. Escherichia coli O157:H7 and other Shiga toxinproducing Escherichia coli (STEC). Available from: http://www.cdc.gov/nczved/divisions/ dfbmd/diseases/ecoli_o157h7/ (accessed 01.10.12).

Difco, M. 1984. Manual of Dehydrated Culture, Media and Reagent for Difcolaboratories,Detroit,Michigan,USA. pp:5-5.

Furrer, B., U. Candrian, Ch.Hocfelein and J. Leuethy.1991. Detection and identification of Listeria monocytogenes in cooked sausage products and in milk in vitro amplication of haemolysin gene fraginents. J. Appl. Bacteriol. 70: 372 -379 .
Gelbicova, T. and R . Karpiskova. 2012. Outdoor environment as a source of Listeria monocytogenes in food chain. Czech Journal of Food Sciences, 30:83-88.

Gopo, J.M, R. Melis, E. Filipska and J. Filipski. 1988. Development of a specific biotinylated DNA probe for rapid identification of Salmonella. Mol Cell Probes 2:271-280

Jacquelyn. G. and B. P. Hall. 1993.Microbiology: Principles and Explorations.pp: 65.

Jamali, H., M. Paydar, S. Ismail, C. Y. Looi, W. F. Wong, B. Radmehr and A. Abedini. 2015. Prevalence, antimicrobial susceptibility and virulotyping of Listeria species and Listeria monocytogenes isolated from open-air fish markets. BMC Microbiology. 15- 144.

James, G. S. 2010.Universal bacterial identification by PCR and DNA sequencing of 16S rRNA gene pp: 209-214.

John, M.S., Bartlet and D. Striling.1990. Methods in molecular biology: PCR protocols, volume 226: 53-54.

Klein, P.G. and V.K. Juneja. 1997.Sensitive detection of viable Listeria monocytogenes by reverse transcriptionPCR. Appl Environ Microbiol 63:4441-4448.

Kuhn, M., and W. Goebel.1989. Identification of extracellular protein of Listeria monocytogenes possibly involved in intracellular uptake by mammalian cells. Infect Immun. 57:55-61.

Lakicevic, B., O. Buncic, V. Katic, Z. Lepsanovic, Lj. Petrovic, V. Jankovic and P. Ikonic. 2014. Detection of Listeria spp. during production and ripening of Petrovská klobása. Acta Vet. 64:367-377.

Leight, A. K., B. C. Crump and R. R. Hood. 2018. Assessment of fecalindicator bacteria and potential pathogen cooccurrence at a shellfishgrowing area. Front. Microbiol. 9:384-397.

MacFaddin, J. F. 1985. Media for Isolation-CultivationIdentification-Maintenance of Medical Bacteria, Vol. 1, Williams and Wilkins, Baltimore. pp: 240-240. 
Maureau, P., I. Derclaye, D. Gregorie, M. Janssen, G.R. Cornelis.1989. Campylobacter species identified on polymorphism of DNA encoding rRNA. J Clin Microbiol 27:1514-1517.

Mohamed, Y., W. W. Reda, K. Abdel-Moein, K. A. Abd ElRazik, A.M.A. Barakat, H. A. El Fadaly, N. A. Hassanain and, A.G. Hegazi. 2016. Prevalence and phylogenetic characterization of Listeria monocytogenes isolated from processed meat marketed in Egypt Journal of Genetic Engineering and Biotechnology. 14: 119-123.

Moreno, L. Z., R. Paixao, D. D. de Gobbi, D. C. Raimundo, T. S. P. Ferreira, A. M. Moreno and M. H. Matte. 2014. Phenotypic and genotypic characterization of atypical Listeria monocytogenes and Listeria innocua isolated from swine slaughterhouses and meat markets. BioMed Research International: 1-12. doi:10.1155/2014/ 742032.

Ray, B. 2004. Fundamental food microbiology (3rd ed.). Boca Raton, FL: CRC Press. chapter3. pp: 8-8.

Ruppitsch, W., A. Pietzka, K. Prior, S. Bletz, H .L. Fernandez, F. Allerberger, D. Harmsen and A. Mellmann. 2015. Defining and evaluating a core genome multilocus sequence typing scheme for whole-genome sequencebased typing of Listeria monocytogenes. J. Clin. Microbiol. 53:2869-2876.
Schuppler, M., and M.J. Loessner. 2010. The Opportunistic pathogen Listeria monocytogenes: Pathogenicity and interaction with the mucosal immune system. Int. J. Inflam. 14:1-12.

Swaminathan, S., A. C. Kile., E. M. MacDonald., and D.M. Koepp 2007. Yra1 is required for S phase entry and affects Dia2 binding to replication origins. Mol Cell Biol 27(13):4674-84.

Thompson, J.D., T.J. Gibson, F. Plewniak, F. Jeanmougin, and D.G. Higgins. 1997. The CLUSTAL_X windows interface: flexible strategies for multiple sequence alignment aided by quality analysis tools. Nucleic Acids Res. 25: 4876-4882.

Vanderzant, C., and D. F. Splittstoesser . 1992. Compendium of methods for the microbiological examination of foods, 3rd ed. American Public Health Association, Washington, D.C. pp: 181-186.

Wang, G., W. Qian, X. Zhang, H. Wang, K. Ye, Y. Bai and G. Zhou. 2015. Prevalence, genetic diversity and antimicrobial resistance of Listeria monocytogenes isolated from ready-to-eat meat products in Nanjing, China. Food Control. 50:202-208.

\section{الملخص العربي}

دراسات وراثية جزيئية على تأثثر بعض المستخلصات النباتية المضادة للجراثيم على التعبير الجيني

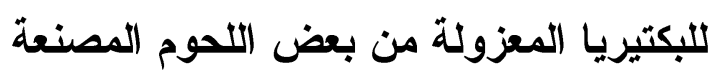

منى مخيمر حسن, سامية عبداله عبد العزيز, أسماء محمد مجاهد الفزماوي, هاجر أبو العزايم عبد الرسول, ياسر محمد مبروك

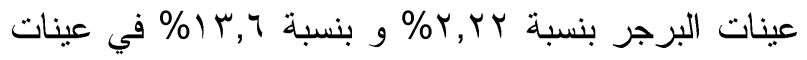
الانشون ولم تظهر النتائج أبي تواجد لبكتريا الليزتيريا في

عينات اللحم المفروم. وللتاكيد من نواجد وتوزيع بكتريا الليزتيريا في عينات اللحوم المختلفة تم إجراء اختبار صبغة جرام و التوصيف الشكلي و الجزيئي من خلال إجراء تفاعل البلمرة المنسلسل المتخصص لجين 1 sRNA و التاكيد الدقيق باجراء تحليل تتابع الجينات وأيضا اجراء تفاعل

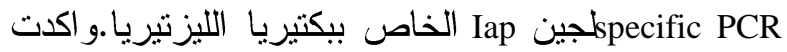
جميع الاختبارات الميكروبيولوجية والوراثية نواجد هذة البكتريا Listeria في عينات اللحوم المصنعة بالنسب

$$
\text { المذكورة أعلاه. }
$$

في هذه الدراسة تم الكثف عن وجود بكتريا الليزنيريا وذلك بفحص ثلاثة أنواع من اللحوم المصنعة وهي اللانشون والبرجز و اللحم المفروم وذلك من خلال تجميع عينات من الأسواق المحلية من ثلاث شركات مختلفة. وتم تتمية جميع العزلات البكتيرية علي أوساط غذائية متخصصة بعد الزراعة المبدئية للعزلات. وتعتمد شكل المستعمرات البكتيرية علي نوع الوسط الغذائي المستخدم

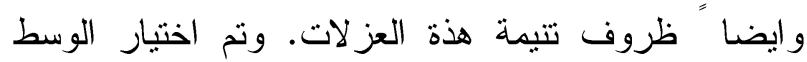
الغذائي Oxford listeria agar base medium ذللك لأنه متخصص بشكل دقيق للكثف عن بكتيريا الليزتيريا. و اوضحت نتائج هذة الدراسة أن نوزيع بكتريا الليزتيريا في بيحي 